УДК 37. 015. 311

DOI: https://doi.org/10.35619/iiu.v0i9.130

Стельмашук Жанна

кандидат педагогічних наук, доцент кафедри теорії і методики виховання Рівненського державного гуманітарного університету, м. Рівне, Україна ORCID: 0000-0003-2368-4209, e-mail: zhanna.stelmashuk@rshu.edu.ua кандидат педагогічних наук, старший викладач кафедри теорії і практики фізичної культури і спорту Рівненського державного гуманітарного університету, м. Рівне, Україна ORCID: 0000-0003-1545-0867, e-mail: alinavakoliuk@ukr.net

\title{
ДО ПРОБЛЕМИ РОЗВИТКУ ЕМОЦЙНОГО ІНТЕЛЕКТУ ОСОБИСТОСТІ
}

\begin{abstract}
Анотація. У статті на основі здійсненого теоретичного аналізу розкрито сутність феномену емоційного інтелекту як особливого конструкта та здатності особистості.

Приділено увагу вітчизняним та зарубіжним концепціям у розумінні емоційного інтелекту, їх спільним та відмінним позиціям стосовно його структури та генези розвитку.

Доведено, що термін «емоційний інтелект» розглядається як здатність до розпізнання, розуміння емоцій і управління ними; служить для визначення сукупності здібностей, знань та вмінь, пов'язаних з регуляцією емоційної сфери особистості, необхідних для успішної соціалізації та комунікації.

Схарактеризовано дві форми репрезентації поняття «емоційний інтелект»: міжособистісний емоційний інтелект (спроможність людини розуміти інших людей, усвідомлювати мотиви їхньої діяльності, ставлення їх до роботи, вирішувати, як краще співпрацювати 3 цими людьми) та внутрішньоособистісний емоційний інтелект (властивість людини, спрямована на себе: спроможність формувати точну адекватну модель власного «я» та використовувати цю модель, щоб ефективно функціонувати у житті).

Обгрунтовано доцільність розглядати емоційний інтелект як інтегральну властивість особистості, що забезпечує здатність розуміти емоції та управляти ними через когнітивну обробку емоційної інформації.

Зроблено висновок, що емоційний інтелект як наскрізне уміння учня Нової української школи знайшло своє обгрунтування у наукових дослідженнях 3 психології, але $\epsilon$ недостатньо дослідженим у педагогічній теорії та практиці.

Ключові слова: емоційний інтелект, розвиток, особистість, Нова українська школа, наскрізне уміння.
\end{abstract}

Постановка проблеми. Ключовим акцентом нормативно-правових актів 3 питань освіти (Закон України «Про середню освіту», Концепція «Нова 
українська школа» та ін.) є філософія Нової української школи, яка закладає фундамент для успіху та самореалізації особистості, формування цілісної індивідуальності, 3 увагою до інтелектуального, духовного, емоційного, соціального та фізичного розвитку, що $є$ передумовою життєвого успіху дитини, iї щастя.

Відповідно до Закону України «Про загальну середню освіту» одним із пріоритетних завдань освіти $€$ виховання свідомого ставлення до свого здоров'я та здоров'я інших громадян як найвищої соціальної цінності, формування гігієнічних навичок і засад здорового способу життя, збереження i зміцнення фізичного та психічного здоров'я учнів (вихованців) (Закон України «Про загальну середню освіту», 2018).

Програма «Нова українська школа» у поступі до цінностей» визначає мету виховання як «розвиток морально-духовної особистості, здатної бути повноцінним суб'єктом суспільно значущих соціальних взаємин» (Програма «Нова українська школа» у поступі до цінностей, 2018).

Таке соціальне замовлення актуалізує необхідність розвитку емоційного інтелекту як одного з наскрізних умінь учня Нової української школи. Адже, емоційний інтелект є однією з головних складових у досягненні успіху.

Аналіз останніх досліджень 3 проблеми. Проблема емоційного інтелекту знайшла своє обгрунтування в наукових положеннях зарубіжних спеціалістів: Р. Бар-Он (Bar-On, 1997), Г. Гарднер (Gardner, 1983, 1993), Д. Гоулман (Goleman (Гоулман (Goleman), 2011)) , Дж. Мейер, П. Селовей (Mayer and Salovey, 1993, 1995) та ін.

Змістові, структурно-динамічні та функціональні особливості емоційного інтелекту $\epsilon$ предметом наукової уваги сучасних психологів І. Андрєєвої (Андреева, 2006), Г. Бреслава (Бреслав, 2007), Д. Люсіна (Люсін, 2004), Н. Ковриги, Е. Носенко (Носенко та Коврига, 2003) та ін.

Наразі об'єктивно виникає потреба уточнити сутність та варіативність підходів щодо тлумачення поняття «емоційний інтелект» як наскрізне уміння учня Нової української школи , що є метою представленої наукової розвідки.

Виклад основного матеріалу дослідження. Здійснений аналіз наукових джерел дав підстави констатувати, що проблема розвитку емоційного інтелекту особистості сьогодні є однією з найактуальніших у дослідженнях 3 психології та водночас малодослідженою у педагогічній науці.

Пошук тлумачення поняття «емоційний інтелект» у довідковій літературі 3 психології та педагогіки засвідчив, що сьогодні немає його загальноприйнятого визначення. Так, приміром, у педагогічних словниках наявний лише термін «інтелект» 3 його різновидами (природний, штучний). Натомість у «Психологічному словнику-довіднику» (2012) емоційний інтелект визначається як «здатність сприймати і розуміти емоційні прояви особистості, керувати емоціями на основі інтелектуальних процесів. Індивіди 3 високим рівнем розвитку емоційного інтелекту володіють здібностями до розуміння власних емоцій і емоцій інших людей, до управління власною емоційною сферою» (Приходько та Юрченко, 2012, с. 62).

У монографії українських дослідників Е. Носенко та Н. Ковриги (2003) (Носенко та Коврига, 3003) «Емоційний інтелект: концептуалізація феномену, основні функції» зазначено, що «поняття емоційний інтелект з'явилось у перебігу в психологічній літературі 3 виходом у світ відомої монографії Говарда Гарднера «Frames of mind» у 1983 р. (Gardner, 1983). Власне у цій 
праці вперше було обгрунтовано необхідність переглянути тлумачення поняття інтелект, що вимірювалось за допомогою коефіцієнта інтелектуального розвитку IQ, розширивши його (Носенко та Коврига, 2003, с.24). На думку авторів, Гарднер висловив припущення, що існує не один єдиний тип інтелекту, який впливає певним чином на успіх життєдіяльності людини, а скоріше достатньо широкий спектр підвидів інтелекту з сімома основними варіантами. Запропонований ним перелік підвидів інтелекту включав: вербальний, логіко-математичний, просторовий, кінестичний, музичний та емоційний види інтелекту. Останній Гарднер підрозділив ще на два підвиди: внутрішньоособистісний і міжособистісний.

Міжособистісний інтелект раніше вже фігурував у психологічній літературі під назвою соціального інтелекту, або соціальної компетентності. Він характеризує вміння людини взаємодіяти з іншими людьми.

Внутрішньоособистісний інтелект передбачає вміння людини самореалізуватись у житті, мотивувати себе на активну діяльність та досягнення успіху» (Носенко та Коврига, 2003, с.24).

Слід зауважити, що згодом за авторством Говарда Гарднера (Гарднер, $1993)$ було опубліковано працю «Множинність виявлення інтелекту» (1993), де було подано більш детальне визначення поняття «емоційний інтелект» у двох формах його репрезентації: міжособистісний емоційний інтелект (спроможність людини розуміти інших людей, усвідомлювати мотиви їхньої діяльності, ставлення їх до роботи, вирішувати, як краще співпрацювати 3 цими людьми) та внутрішньоособистісний емоційний інтелект (властивість людини, спрямована на себе: спроможність формувати точну адекватну модель власного «я» та використовувати цю модель, щоб ефективно функціонувати у житті).

Е. Носенко та Н. Коврига зосередили увагу на окремих уточненнях Г. Гарднером тлумачення поняття: «... Гарднер додав до тлумачення міжособистісного емоційного інтелекту наявність у людини спроможності правильно розпізнавати настрої, вияви темпераменту, мотивів та прагнень інших людей і відповідним чином реагувати на них. Що стосується уточнення поняття внутрішньоособистісного інтелекту, то до його визначення були додані наступні деталі. Вунтрішньоособистісний інтелект - це спроможність людини розуміти власні почуття, їх витоки і регулювати на цій основі власну поведінку» (Носенко та Коврига, 2003, с.25).

Більш деталізоване тлумачення компонентів емоційного інтелекту можна віднайти у працях американських психологів Джона Мейера і Пітера Саловея (Мейєр та Саловей, 1995, с.435). Вони розглядали емоційний інтелект як «спроможність регулювати власні почуття та почуття інших людей, розпізнавати їх адекватно для того, щоб спрямовувати своє мислення та діяльність». Згодом психологи переглянули та запропонували таке трактування поняття: «Емоційний інтелект включає здібність адекватно сприймати, оцінювати та виражати емоції; спроможність породжувати почуття, коли вони сприяють мисленню; спроможність розуміти емоції та знання, що стосуються емоцій, а також здібність регулювати емоції, щоб сприяти власному емоційному та інтелектуальному зростанню» (Мейєр та Саловей, 1995).

Р. Варон під емоційним інтелектом розумів всі некогнітивні здібності, знання і компетентність, що дають людині можливість успішно справлятися 3 різними життєвими ситуаціями. Дослідником встановлено п’ять великих сфер 
компетенцій, в кожній 3 яких відзначаються такі специфічні навички, що ведуть до досягнення успіху: пізнання власної особистості (поінформованість про власні емоції, впевненість у собі, самоповага, самореалізація, незалежність); міжособистісне спілкування (міжособистісні взаємини, соціальна відповідальність, співпереживання), адаптація (рішення проблем, оцінка реальності, пристосування), управління стресовими ситуаціями (стійкість до стресу, імпульсивність, контроль), переважаючий настрій (щастя, оптимізм) (Мейєр та Саловей, 1993).

Натомість психолог Р. Бар-Он (Бар-Он, 1997) емоційний інтелект визначав як сукупність некогнітивних здібностей, компетенцій і навичок, що дають людині можливість успішно впоратися 3 викликами i впливом зовнішнього середовища та протистояти його тиску. Це, на думку дослідника, забезпечує здатність людини успішно пристосовуватися до соціуму, налагоджувати міжособистісну взаємодію, управляти своєю поведінкою в стресових ситуаціях

Активним популяризатором емоційного інтелекту (EQ) вважається Д. Гоулман, американський журналіст і психолог, який у праці «Emotional Inteligence» на матеріалах психологічних досліджень та опитувань довів, що успіх в житті залежить не стільки від логічного інтелекту IQ, скільки від здібностей керувати своїми емоціями EQ. У дослідженнях Д. Гоулмана (Гоулман, 2011) емоційний інтелект трактується як «особистісна властивість, здатність людини пояснювати власні емоції та емоції оточуючих 3 тим, щоб використовувати отриману інформацію для реалізації власних цілей».

Р. Бояцис і Д. Гоулман виділяють такі компоненти емоційного інтелекту:

1) самосвідомість (емоційне усвідомлення себе, точна самооцінка, впевненість у собі);

2) соціальне усвідомлення (емпатія, організаційне усвідомлення, орієнтація на обслуговування);

3) самокерування (самоконтроль, адаптивність, ініціатива, орієнтація на досягнення);

4) соціальні навички (лідерство, вплив, комунікація, вирішення конфліктів, робота у групі).

На думку російського психолога Г. Бреслава, поняття «емоційний інтелект» дало поштовх для перегляду змісту емоційної сфери особистості, оскільки « люди відрізняються не лише тим, які у них емоційні явища і як вони протікають, але і за тим, як вони вміють з ними обходитися» (Бреслав, 2004).

Д. Люсін (Люсин, 2004) пропонує двокомпонентну структуру емоційного інтелекту як здатності до розуміння своїх і чужих емоцій, управління ними. Автор вводить поняття внутрішньоособистісного (розуміння власних емоцій та управління ними) та міжособистісного (розуміння емоцій інших людей i управління ними) емоційного інтелекту.

Дослідниця I. Андрєєва зауважує, що «емоційний інтелект лежить в основі емоційної саморегуляції, а високий рівень емоційного інтелекту дає можливість розуміти власні емоції та емоції інших людей, керувати емоційною сферою; допомагає приймати рішення на основі відображення і осмислення емоцій, які мають для особистості певний зміст. Емоційний інтелект складається з вміння свідомо керувати емоціями, розуміти емоції, асимілювати емоції в мислення, розрізняти та виражати емоції» (Андрєєва, 2006). 
Отже, з огляду на проведений порівняльно-еволюційний аналіз, явище «емоційний інтелект» розглядається як здатність до розпізнання, розуміння емоцій і управління ними; служить для визначення сукупності здібностей, знань та вмінь, пов'язаних 3 регуляцією емоційної сфери особистості, необхідних для успішної соціалізації та комунікації. Вчені одностайні у тому, що емоційний інтелект поєднує у собі вміння розрізняти та розуміти емоції, керувати власним емоційним станом та емоціями партнерів зі спілкування.

Висновки і перспективи подальших розвідок. Аналіз наукових джерел дав підстави зробити висновок, що емоційний інтелект як наскрізне уміння учня Нової української школи знайшов своє обгрунтування у наукових дослідженнях 3 психології, але може стати предметом наукових пошуків у педагогіці.

Перспективи подальших наукових розвідок вбачаємо у дослідженні методів та засобів розвитку емоційного інтелекту учнів різних вікових категорій у світлі основних положень Нової української школи.

\section{СПИСОК ВИКОРИСТАНИХ ДЖЕРЕЛ:}

Міністерство освіти і науки України, (2017). Закон України «Про загальну середню освіту». Київ: Верховна Рада України.

Програма «Нова українська школа» у поступі до цінностей, (2018). Київ: Національна академія педагогічних наук України, $40 \mathrm{c}$.

Bar-On, R. (1997). The Bar-On Emotional Quotient Inventory: Technical Manual. Toronto : Multi-Health Systems, 1997. 216 p.

Gardner, H. (1983). Frames of mind: The theory of multiple intelligences. New York: Basic Books. 440 p. $478 \mathrm{c}$.

Гоулман, Д. (2011). Эмоцииональный интеллект. Москва : АСТ: Астрель.

Mayer, J.D., and Salovey, P. (1993). The Intelligence of emotional intelligence. Intelligence. V.17. N4. p.433-442.

Mayer, J. and Salovey, P. (1995). Emotional intelligence and the construction and regulation of feelings. Applied and Preventive Psychology. V.4. P.197-208.

Андреева, И. (2006). Эмоциональный интеллект: исследование феномена. Вопросы психологии. №3. сс. 78-86.

Бреслав, Г. (2007). Психология эмоциии. 3-е издание, стереотипное. Москва : Смысл : Академия. 544 с.

Люсин, Д. (2004). Структура эмоционального интеллекта и связь его компонентов с индивидуальными особенностями: эмпирический анализ. Социальный интеллект: теория, измерение, исследования. Москва: ИП РАН. № 4. Cc. 129-140.

Носенко, Е та Коврига, Н. (2003). Емоційний інтелект: концептуалізація феномену, основні функиії. Київ: Вища школа. 126 с.

Приходько, Ю та Юрченко, В. (2012). Психологічний словник-довідник. Київ: Каравела. 328 с.

\section{REFERENCES:}

Ministerstvo osvity i nauky Ukrainy, (2017). Zakon Ukrainy «Pro zahalnu seredniu osvitu». Intelekt [The Law of Ukraine "On General Secomdary Education"]. Kyiv: Verkhovna Rada Ukrainy. [in Ukrainian].

Prohrama "Nova ukrainska shkola" u postupi do tsinnostei intelekt [Program "New Ukrainian School" in Advancing Values]. (2018). Kyiv: Natsionalna akademiia pedahohichnykh nauk Ukrainy, $40 \mathrm{~s}$. [in Ukrainian]. 
Bar-On, R. (1997). The Bar-On Emotional Quotient Inventory: Technical Manual. Toronto : Multi-Health Systems, 1997. 216 p. [in English].

Gardner, H. (1983). Frames of mind: The Theory of Multiple Intelligences. New York: Basic Books. 440 p. [in English].

Goulman. D. (2011). Emotsionalnyy intellekt. [Emotional Intelligence]. Moskva : AST: Astrel. 478 s. [in Russian].

Mayer, J.D., and Salovey, P. (1993). The Intelligence of Emotional Intelligence. Intelligence. V.17. N4. P.433-442. [in English].

Mayer, J. and Salovey, P. (1995). Emotional Intelligence and the Construction and Regulation of Feelings. Applied and Preventive Psychology. V.4. P.197-208. [in English].

Andreyeva. I. (2006). Emotsionalnyy intellekt: issledovaniye fenomena [Emotional Intelligence: a Study of the Phenomenon]. Voprosy psikhologii. No 3. ss. 78-86. [in Russian].

Breslav. G. (2007). Psikhologiya emotsiy [Psychology of Emotions], 3-e izdaniye. stereotipnoye. Moskva : Smysl : Akademiya. 544 s. [in Russian].

Lyusin. D. (2004). Struktura emotsionalnogo intellekta i svyaz ego komponentov s individualnymi osobennostyami: empiricheskiy analiz. [The Structure of Emotional Intelligence and the Relationship of its Components with Individual Characteristics: an Empirical Analysis]. Sotsialnyy intellekt : teoriya. izmereniye. issledovaniya. Moskva: IP RAN. No 4. ss. 129-140. [in Russian].

Nosenko, E \& Kovryha, N. (2003). Emotsiinyi intelekt: kontseptualizatsiia fenomenu, osnovni funktsii. [Emotional Intelligence: Conceptualisation of the Phenomenon, the Main Functions]. Kyiv: Vyshcha shkola. 126 s. [in Ukrainian].

Prykhodko, Yu ta Yurchenko, V. (2012). V: Psykholohichnyi slovnyk-dovidnyk. [Psychological dictionary-directory]/ Kyiv: Karavela. 328 s. [in Ukrainian].

\title{
ON THE ISSUE OF THE DEVELOPMENT OF EMOTIONAL INTELLIGENCE OF A PERSONALITY
}

\author{
Zhanna Stelmashuk \\ Candidate of Pedagogical Sciences, \\ Associate Professor at the Department of Theory \\ and Methods of Education \\ Rivne State University of the Humanities, \\ Rivne, Ukraine \\ ORCID: 0000-0003-2368-4209, \\ e-mail: zhanna.stelmashuk@rshu.edu.ua,
}

\begin{abstract}
Alina Vakoliuk
Candidate of Pedagogical Sciences, Senior Lecturer at the Department of Theory and Practice of Physical Culture and Sports Rivne State University of the Humanities, Rivne, Ukraine ORCID : 0000-0003-1545-0867, e-mail: alinavakoliuk@ukr.net
\end{abstract}

\footnotetext{
Abstract. In the article on the basis of the realized theoretical research the essence of the phenomenon of individual emotional intelligence as a special construct and personality's ability is revealed.

The attention is paid to Ukrainian and foreign concepts in the emotional intelligence, their common and different positions regarding to its structure and genesis of the development. It is proved that the concept "emotional intelligence" is considered as the ability to recognize, understand emotions and manage them; it serves to determine the
} 
totality of abilities, knowledge and skills related to the regulation of the emotional sphere of a personality, necessary for successful socialization and communication. It is found out, that an emotional intellect combines in itself ability to distinguish and understand emotions, to manage by own emotional state and partners' emotions in the process of communication.

Two forms of representation of the concept of "emotional intelligence" are described: interpersonal emotional intelligence (the ability of a person to understand other people, to understand the motives of their activity, their relation to work, to decide how to better co-operate with these people) and internal personality emotional intelligence (the property of a person directed to himself : the ability to formulate an exact, adequate model of the personal "I" and to use this model to function effectively in life).

The expediency of considering the emotional intelligence as an integral property of the individual, which provides the ability to understand emotions and manage them through the cognitive processing of emotional information, is substantiated.

It is concluded that the emotional intelligence as the transcending ability of a student of the New Ukrainian School has found its basis in research on psychology, but is not sufficiently studied in pedagogical theory and practice.

Key words: emotional intelligence, development, personality, New Ukrainian school, cross-cutting skills.

Стаття надійшла до редакиії 25.03.2019 p. 